\title{
Belajar Praktik Pemberdayaan Masyarakat melalui pembentukan Desa Wisata
}

\author{
Yusuf Adam Hilman \\ Universitas Muhammadiyah Ponroogo, Indonesia \\ Email: adam_hilman@umpo.ac.id
}

\begin{abstract}
Tourism Villages were established with the aim of optimizing their local potential, so that people around the village feel the effects of these efforts, including: improving the economy of local communities, vibrant social activities, increasing infrastructure development are things that are seen to change in a tourist village. The process of making a Tourism Village requires synergy from all parties so that it can run smoothly, in the process there are activities that move the community to be more empowered and have fighting power and innovation, so that there are various forms of community empowerment practices in a tourist village, this is interesting. To find the right model in exploring the uniqueness of tourist villages, this study uses a type of library receipt using secondary data, from research results, journals and books. This study shows that the form of community empowerment is clearly visible from the various processes of creating a tourist village, thus enabling the village to become a place of learning for the general public, tourists, and students.
\end{abstract}

Keywords: Village; Tourism; Community empowerment.

\begin{abstract}
Abstrak
Desa Wisata di dirikan dengan tujuan untuk mengoptimalisasikan potensi lokal yang dimiliki, agar masyarakat di sekitar desa merasakan efek dari upaya tersebut, diantaranya: meningkatkan perekonomian masyarakat lokal, semaraknya aktifitas sosial, peningkatan pembangunan infrastruktur menjadi hal yang terlihat berubah di sebuah desa wisata. Proses pembuatan Desa Wisata memerlukan sinergitas dari semua pihak supaya dapat berjalan dengan lancar, dalam proses tersebut terdapat aktifitas - aktifitas yang menggerakan masyarakat supaya lebih berdaya serta memiliki daya juang dan inovasi, sehingga terdapat berbagai bentuk praktik pemberdayaan masyarakat dalam sebuah desa wisata, hal ini menarik untuk dicari model yang tepat dalam menggali keunikan desa wisata, Kajian ini menggunakan jenis library resit dengan menggunakan data sekunder, dari hasil penelitian, jurnal dan buku. Kajian ini memperlihatkan bentuk pemberdayaan masyarakat Nampak secara jelas dari berbagai proses pembuatan desa wisata, sehingga memungkinkan desa tersebut menjadi tempat belajar bagi, masyarakat umum, wisatawan, dan juga pelajar.
\end{abstract}

Kata Kunci: Desa; Wisata; Pemberdayaan Masyarakat.

\section{A. PENDAHULUAN}

Pendapatan Negara selama ini bertumpu pada sektor pajak, tercatat dalam interval tahun 2007 hingga tahun 2017 penerimaan pajak terus mengalami kenaikan, hal ini memperlihatkan jika pajak tetap menjadi sumber utama dari penerimaan Negara.

Peningkatan penerimaan negara dari sektor pajak, memang tidak bisa dipungkiri, karena terus mengalami peningkatan dalam kurun waktu 10 tahun terakhir, akan tetapi perlu di catat bahwa masih banyak persoalan yang terjadi dalam pelaksanaanya di lapangan, beberapa sumber menyebutkan jika target penerimaan pajak belum mencapai target, Tidak tercapainya target penerimaan pajak pada tahun 2014 dan 2015, banyak yang menyebutkan karena tingginya target yang dibebankan, di tengah kondisi

* Corresponding author

Received: Octobber 23, 2020; Revised: November 10, 2020; Accepted: December 21, 2020 
perekonomian yang sedang mengalami perlambatan, sehingga target tersebut dianggap sangat fantastis dan sulit untuk memenuhinya (Ginting, 2015).

Persoalan kedua adalah pelaksanaan kebijakan pajak, yang memberlakukan pengampunan pajak lewat program tax amnesty, dianggap masih banyak persoalan ketika di lakukan di lapangan, sehingga pemenuhan target pajak belum juga bisa optimal.

Tabel 1 Penerimaan Pajak Tahun 2007 s/d 2017 Republik Indonesia

\begin{tabular}{cc}
\hline Tahun & Penerimaan Pajak \\
\hline 2007 & Rp. 440.988,- \\
\hline 2008 & Rp.658.701,- \\
\hline 2009 & Rp.619.622,- \\
\hline 2010 & Rp.723.307,- \\
\hline 2011 & Rp.873.874,- \\
\hline 2012 & Rp.980.518,- \\
\hline 2013 & Rp.1.007.306,- \\
\hline 2014 & Rp.1.146.865,- \\
\hline 2015 & Rp.1.240.418,- \\
\hline 2016 & Rp.1.284.970,- \\
\hline 2017 & Rp.1.472.700,- \\
\hline 2018 & Rp.1.618.095,-
\end{tabular}

\section{Sumber diolah dari: (Asri \& Permana, 2019)}

Pelaksanaan kebijakan perpajakan di Indonesia masih banyak menimbulkan persoalan, diantaranya: 1). Rendahnya kepatuhan dari wajib pajak, 2). Wewenang yang masih cukup besar dari Direktorat Jenderal Pajak (DJP), meliputi fungsi-fungsi seperti: eksekutif, legislatif, dan yudikatif, yang menyebabkan keadilan dalam memberikan pelayan kepada wajib pajak, 3). Rendahnya kepercayaan masyarakat terhadap aparat pajak, selain itu aturan - aturan yang ada terkadang terkesan rumit (Pravasanti, 2018). Tax Amnesty beresiko gagal, jika dilakukan terlalu lama sehingga akan menimbulkan penurunan kepatuhan (Voluntary Compliance) dari wajib pajak, terlebih lagi jika kebijakan ini tidak dibarengi dengan program yang tidak tepat (Santoso \& Setiawan, 2009). Selain persoalan pemenuhan target pajak yang belum optimal, dan kebijakan tax amnesty, ternyata penerimaan negara masih sangat bergantung pada sektor pajak, dominasi sektor pajak yang mendekati angka $80 \%$ sebagai sumber penerimaan negara, berakibat pada jumlah serapan anggaran dan belanja negara menjadi kurang optimal.

Kondisi tersebut pada akhirnya membuat capaian yang di inginkan oleh negara sesuai amanat konstitusi yakni untuk mewujudkan negara yang sejahtera belum dapat terwujud, kondisi tersebut mengharuskan pemerintah untuk berfikir lebih kreatif yakni dnegan cara penggalian sumber pendapatan baru non pajak, yang dapat meningkatkan cadangan dana yang dimiliki (Dinarjito, 2017).

Melihat perkembangan sumber utama pendapatan negara yakni pajak melalui diskursus yang dijelaskan pada paragraph sebelumnya, mengharuskan pemerintah untuk melakukan penggalian terhadap alternatif pendapatan lain atau sumber penerimaan baru di luar pajak, Pada tahun 2015 di peroleh sebuah gambaran jika pendapatan negara bukan pajak nilainya masih cukup kecil yakni mencapai 15\% dengan total angka sebesar 269,1 Triliyun rupiah (Wahidah, 2017).

PNBP atau penerimaan Nasional Bukan Pajak merupakan segala jenis penerimaan yang diperoleh dari pengelolaan dana pemerintah, penerimaan dari hasil pengelolaan sumberdaya alam, penerimaan dari 
hasil kekayaan Negara yang dipisahkan, penerimaan dari hasil pelayanan pemerintahan yang telah diatur oleh undang - undang (Ahdika, 2018).

Penggalian terhadap potensi PNBP memang perlu difikirkan secara bijak, dimana sumber pendapatan tersebut bisa terus digali dan ditingkatkan nilai nya, supaya benar - benar optimal, kondisi tersebut kemudian disikapi oleh pemerintah melalui program Nawa Cita, yang mencoba melakukan model pemerataan pembangunan berbasis grassrot dimana desa di jadikan sebagai garda terdepan, melalui program - program padat karya, yang bisa meningkatkan pendapatan negara.

Caranya yakni dengan melakukan berbagai program berbasis masyarakat sebagai upaya padat karya, hal tersebut dapat dilakukan melalui kelembagaan desa, usaha tersebut nantinya diharapkan dapat memberikan efek terhadap masyarakat di lapisan paling bawah, guna menyelesaikan persoalan persoalan kesenjangan dan juga pemerataan kesejahteraan serta kesempatan mendapatkan penghidupan yang layak (Syamsi, 2015).

Berbicara tentang pemerataan pembangunan khususnya di daerah pinggiran diharapkan dapat menjadikan desa kembali mencuat memiliki posisi strategis dalam praktik pembangunan, posisi desa kembali menjadi trigger atau pemantik pasca lahirnya undang - undang no 06 Tahun 2014, yang mengembalikan posisi desa sebagai wilayah yang strategis, dengan dukungan finansial yang memadai, dan porsi kewenangan yang cukup, sehingga desa dapat melakukan berbagai macam praktik pemberdayaan dan juga pembangunan yang lebih konteksual dengan keadaan di lapangan. Dukungan finasial yang di peroleh desa memiliki nilai yang besar, yakni mencapai 1 Milyar Rupiah yang digunakan untuk pembiayaan operasional dan belanja pegawai, selain itu juga digunakan untuk mendanai aktifitas pembangunan fisik dan juga non fisik, kegiatan pembangunan fisik meliputi: pembangunan infrastruktur jalan, pembangunan irigasi, bendungan dan lain - lain, sedangkan pembangunan non fisik, bisa dialokasikan untuk kegiatan - kegiatan pemberdayaan masyarakat (Srirejeki, 2015).

Praktik pemberdayaan masyarakat seringkali kita jumpai di berbagai wilayah di Indonesia, khususnya yang dilakukan oleh pemerintah desa, ragamnya sangat banyak, namun ada beberapa program pemberdayaan masyarakat yang kemudian lahir dari aktifitas kemandirian desa, diantaranya kegiatan desa wisata, yang berangkat dari potensi lokal yang terus digali dan dikembangkan sebagai sebuah upaya masyarakat lokal dalam menciptakan kemandirian, supaya dapat menciptakan kesejahteraan.

Isu yang berkembang terkait desa wisata adalah terciptanya kemandirian masyarakat dalam upaya menciptakan kesejahteraan melalui peningkatan ekonomi lokal di wilayah tersebut (Hery, 2016) beberap ahli berpendapat jika desa wisata secara teknis memperlihatkan sebuah wilayah yang menawarkan keasrian lokal, dengan konten budayanya, aktifitas sosial kemasyarakatan dan juga keindahan alam, yang dapat menambah nilai ekonomis masyarakat sekitarnya (Hermiyanty, 2017).

Pengembangan desa wisata berdampak terhadap kehidupan ekonomi masyarakat, hal tersebut bisa dilihat dari beberapa indikator, yakni: 1). Terbukanya lapangan kerja, 2). Berkurangnya tingkat pengangguran di daerah ketempatan, 3). Meningkatkan pendapatan masyarakat dan juga daya beli, 4). Mampu menjadi sumber - sumber baru untuk membantu pembangunan di kawasan desa ketempatan (Aryani, Sunarti, \& Ari, 2017). Desa wisata membuat wilayah tersebut menjadi berubah, akses jalan menjadi lebih baik, masyarakat mendapatkan sumber perekonomian baru, yang dapat meningkatkan pendapatkan, sehingga masyarakat menjadi lebih sejahtera (Hermiyanty, 2017).

Pengembangan desa wisata membawa efek positif di bidang sosial, ekonomi dan juga kemasyarakatan, bagi penduduk sekitar, selain itu praktik desa wisata mampu menggerakan masyarakat untuk berperan aktif dalam setiap kegiatannya, hal ini menunjukan jika kelembagaan desa wisata bisa menjadi pemantik bagi masyarakat untuk bergerak dan berdaya. 


\section{B. METODE PENELITIAN}

Kajian ini merupakan kajian kepustakaan, yang mencari model baru program pemberdayaan masyarakat dalam proses pembentukan desa wisata. Data yang digunakan merupakan data sekunder berupa, hasil penelitian, jurnal, dan buku. Untuk menguji keabsahan data digunakan triangulasi sumber, dimana data yang sudah dikumpulkan dilakukan croschek sumber, dari beberapa sumber yang dimiliki.

\section{HASIL DAN ANALISIS}

\section{Pemberdayaan Masyarakat}

Konsep pemberdayaan masyarakat berangkat dari pentingnya proses pembangunan yang lebih menitikberatkan pada partisipasi aktif dari masyarakat, sehingga praktik pembangunan bisa lebih semarak dan mampu melakukan rekontekstualisasi terhadap keinginan, kebutuhan, serta aspirasi dari masyarakat, bukan model pembangunan yang kaku dan seragam.

Konsep pemberdayaan diadaptasikan dari istilah empowerment yang berkembang pertama kali di Eropa sejak abad pertengahan, terus berkembang hingga di akhir tahun 1970-an, tahun 1980-an dan awal tahun 1990-an. Kosep pemberdayaan tersebut kemudian mempengaruhi teori-teori yang berkembang belakangan ini (Matdoan, 2015) Kata kunci utama dari praktik pemberdayaan adalah memberikan kesempatan yang lebih besar kepada masyarakat untuk lebih mandiri, otonom, dan mandiri, dalam melakukan praktik - praktik pembangunan dalam rangka memenuhi kebutuhan dan keinginannya (Indrawati, 2016).

Pemberdayaan juga menekankan pada proses, bukan semata-mata hasil (output) dari proses tersebut. Oleh karena itu, ukuran keberhasilan pemberdayaan adalah seberapa besar partisipasi atau keberdayaan yang dilakukan oleh individu atau masyarakat. Semakin banyak masyarakat terlibat dalam proses tersebut, berarti semakin berhasil kegiatan pemberdayaan tersebut. Keberdayaan dalam konteks masyarakat merupakan kemampuan individu berpartisipasi aktif dalam masyarakat (Maryam, 2015).

Aktifitas pemberdayaan memiliki beberapa tujuan, diantaranya: 1). Menjadikan individu, kelompok, serta masyarakat dapat merdeka atau mandiri dalam menentukan nasib nya, 2). Kegiatan pemberdayaan di tujukan untuk mengingkatkan harkat dan mastabat masyarakat dalam kehidupan, sosial, ekonomi, budaya, serta politik, 3). Menciptakan perubahan yang lebih positif bagi kehidupan masyarakat, 4). Menumbuhkan sifat - sifat psositif dalam komunitas masyarakat, seperti: etos kerja yang baik, hemat, efektif, efesien, supaya dapat menciptakan kemandirian (Haris, 2014).

Pemberdayaan masyarakat dapat diwujudkan dalam berbagai program salah satunya adalah program desa wisata. Pengembangan Desa Wisata sebagai program Pemberdayaan masyarakat dimaksudkan untuk memberikan daya sekaligus sebagai salah satu upaya dalam penanggulangan kemiskinan di suatu daerah dengan mengolah potensi lokal yang ada di daerah tersebut (Mustangin, 2017).

\section{Peluang Praktik Pemberdayaan masyarakat dari aktifitas Pelembagaan Desa Wisata}

Desa wisata merupakan salah satu permodelen pariwisata yang dalam kurun waktu beberapa tahun terakhir menjadi popular dan banyak dikembangkan di Indonesia, desa wisata terbentuk dadi berbagai keunggulan lokal desa, yang kemudian di coba di baca sebagai sebuah pelung yang potensial untuk di tumbuhkembangkan sebagai salah satu solusi dalam memberdayakan desa.

Desa wisata dikembangkan sebagai sebuah produk wisata alternatif, diharapkan desa wisata mampu mendorong pembangunan desa secara berkesinambungan, dengan memanfaatkan sarana prasarana yang ada di desa tersebut yang bermanfaat bagi masyarakat, sehingga ada hubungan timbale balik tentunya dengan dukungan semua lapisan masyarakat yang ada (Wiwin, 2019). 
Desa wisata merupakan sebuah perpaduan atau bentuk integrasi antara praktik atraksi, akomodasi dan juga fasilitas yang disuguhkan berdasarkan kondisi sosial, budaya masyarakat yang ada di sebuah desa, sebagai sebuah daya tarik yang memiliki nilai jual (Permadi \& Asmony, 2018)

Praktik pemberdayaan masyarakat dalam aktifitas desa wisata tentu tidak dapat dilepaskan dari kebutuhan - kebutuhan yang muncul akibat aktifitas tersebut, hal ini tentunya harus disesuaikan dengan kebutuhan setempat, menurut kami ada beberapa hal yang penting dan menjadi prioritas yakni upaya penguatan sumberdaya manusia yang ada dalam komunitas tersebut, diantaranya: 1). Peningkatan ketrampilan Manajerial dan administrasi, 2). Peningkatan kemampuan enterprenuership, 3). Peningkatan ketrampilan menyelenggarakan kegiatan dan event 4). Peningkatan kapasitas kepemimpinan leadership dan birokrasi.

Pengelolaan desa wisata terdiri ata beberapa kegiatan, seperti: 1). Pernecanaan, 2). Pengorganisasian, 3). Pergerakan, 4). Evaluasi (Desiati, 2013). Aspek pengelolaan desa wisata merupakan hal penting dalam pengembangan desa, sehingga pengelolaan yang baik akan berpengaruh terhadap penyelenggaraan desa wisata yang optimal (Fitriana \& Utami, 2012). Keterampilan human relations adalah paling banyak kontribusinya terhadap efektivitas desa wisata diikuti dengan keterampilan konseptual dan keterampilan teknis pada desa wisata itu (Revida, 2019) Upaya tersebut dilakukan dalam rangka memperkuat kemampuan masyarakat desa ketempatan, oleh sebab itu para pembuat kebijakan harus bisa memberikan fasilitas dalam mempersiapkan kemampuan manajerial dari para anggota masyarakat, supaya dapat diaplikasikan dalam aktifitas desa wisata.

Produk wisata tercipta melalui interaksi antar komponen masyarakat yang terlibat, dalam praktiknya produk tersebut hadir melalui interaksi sosial yang didasari oleh seting sosial melalui aktifitas produksi, sehingga tercipta produk wisata yang memiliki nilai jual dna berbobot (Waluyo, 2017). Ketrampilan Enterprenuership menjadi penting yakni untuk memperkuat kapasitas masyarakat ketempatan wisata, modelnya bisa berupa pelatihan bahasa asing dan juga pengelolaan homestay sebagai produk unggulan desa wisata (Sihombing \& Smanjuntak, 2019). Kebutuhan akan peningkatan kapasitas enterprenur masyarakat harus menjadi sebuah catatan yang harus diperhatikan, menggingat praktek enteruprenuer menjadi salah satu faktor penting untuk menunjang aktifitas desa wisata, yang memiliki nilai jual dan posisi tawar.

Pembuatan paket wisata yang dilakukan di desa, melalui beberapa tahapan, yakni: 1). Membuat rute perjalanan wisata di desa tersebut, 2). Membuat acara atau event wisata oleh masyrakat, 3). Menentukan biaya paket wisata, 4). Pembuatan sarana publikasi paket wisata dengan brosur dan lain sebagainya (I G. A. O. Mahagangga, 2016)

Pengetahuan tentang manajemen event di sebuah desa wisata sangat penting, hal ini nantinya dapat menunjang sebuah kegiatan yang akan menjadi daya tarik sekaligus pemantik bagi penyelenggaraan aktivitas - aktivitas wisatadi desa tersebut, hal inilah yang kemudian diperlukan bagi setiap pengegrak wisata. Aktivitas wisata merupakan hasil dari kontak serta pergaulan dengan masyarakat yang selanjutnya menjadi sebuah budaya dalam membangun sistem sosial yang bersifat komersial, guna mendapatkan nilai tambah dalam hidup bermasyarakat (Kiswantoro, 2014).

Peran kelompok sadar wisata atau Pokdarwis terlihat dalam aktifitas perencanaan, pengelolaan, dan juga pelaksanaan berbagai atraksi yang telah di ciptakan, selain itu terjalin komunikasi serta bentuk bentuk kerjasama antarsteakholder sehingga ada kesamaan persepsi dan langkah dalam mengembangan desa wisata, hal ini juga memperlihatkan kualitas dan kuantitas dari obyek wisata yang di miliki (Putra, 2013).

Pelembagaan desa wisata juga sangat dipengaruhi oleh sosok seorang pemimpin, selain itu kelembagan pemerintah juga akan memberikan efek terhadap, peluang pengembangan sebuah desa, pola desa wisata yang ada di Indoensia sebagian besar dikembangkan melalui jalur - jalur formal, sehingga 
kapasitas pemimpin dalam hal ini kepala desa atau pemimpin lembaga yang terkait dalam pengembangan desa wisata sangat penting keberadaanya, hal ini juga harus di dukung oleh kualitas birokrasi yang professional, sehingga nanti berbagai program yang diarahkan untuk mengembangkan desa wisata bisa benar - benar efektif.

Kemitraan dalam upaya pengembangan desa wisata bisa di bangun melalui bentuk - bentuk kerjasama antar pemerintah ataupun pengembang dari sektor wisata, seperti program CSR yang dilakukan secara mandiri atau melibatkan pihak ketiga, akademisi ataupun penggiat wisata (Putra A. S., 2015)

Kegiatan desa wisata dilakukan melalui usaha - usaha masyarakat ketempatan yang berbasis kemitraan, tujuannya untuk meningkatkan kepuasan wisatawan dengan meningkatnya jumlah kunjungan wisatawan baik lokal ataupun mancanegara ke obyek wisata (Muchammad Sugianto, 2016) Kemitraan formal melibatkan seluruh steakholder terkait, mulai dari Pemerintah Desa, NGO, Lembaga Swadaya Maysrakat. Masyarakat, serta pihak swasta (Prasiasa, 2017)

Bentuk kemitraan berkontribusi positif yaitu bentuk kemitraan kelola, HGB, dan konsesi. Bentuk kemitraan kontrak sewa kontribusinya sedang terhadap pengembangan ekowisata. Faktor lokasi dan kepemilikan lahan sangat mempengaruhi interaksi dengan seluruh aspek kepariwisataan, khususnya penerimaan pendapatan yang rendah dibandingkan pelaku wisata lain (Wahyuni, 2017).

\section{Prioritas praktik pemberdayaan di Desa Wisata}

Tantangan yang dihadapi dalam praktik pemberdayaan kaitanya dengan pembentukan desa wisata secara sederhana dapat di uraikan dari kemunculan keterbatasn desa baik secara kelembagaan, Kapasitas SDM, hingga potensi yang dimiliki, berdasarkan kajian - kajian tersebut kemudian kami mencoba untuk menetapkan beberapa poin penting, yang menjadi diskursus dalam persoalan tersebut, diantaranya: 1). Peningkatan ketrampilan Manajerial dan administrasi, 2). Peningkatan kemampuan enterprenuership, 3). Peningkatan ketrampilan menyelenggarakan kegiatan, 4). Peningkatan kapasitas kepemimpinan leadership dan professional birokrasi.

Melihat poin penting tersebut, maka pelaksanaan pemberdayaan desa, harus benar dilakukan sesuai dnegan kebutuhan komunitas ataupun kelompok masyarakat yang ada, selain mempersiapkan kemampuan serta ketrampilan dalam rangka mendukung persiapan desa wisata, kegiatan - kegiatan pemberdayaan merupakan salah satu jalan menunju peningkatan kualitas hidup masyarakat.

Penulis mencoba membuat sebuah kerangka, dengan tujuan untuk mempersiakan pelembagaan desa wisata, disini desa wisata harus mampu menjadi penggerak bagi masyarakat, sehingga akan memunculkan sebuah simbiosis antara masyarakat dan juga desa wisata, disinilah kemudan praktik pemberdayana menjadi sebuah jembatan untuk pencapaian kesejahteraan dan kemandirian masyarakat. kemampuan membuat acara atau agenda wisata, yang terakhir adalah mempersiapkan kelembagaan pemerintah.

\section{SIMPULAN}

Praktik pemberdayaan masyrakat dalam rangka penguatan pelembagaan desa wisata harus didasarkan pada kebutuhan dan keinginan masyarakat, sehingga model - model praktik pemberdayaan bisa diterapkan dan dilakukan secara optimal serta kontekstual dengan kondisi yang ada. Penulis merangkum 4 (empat) poin penting dalam rangka untuk memperkuat upaya pemberdayaan, yakni: memperkuat kapasitas manajemerial dan administrasi, mengembangkan jiwa enterenuer, memperkuat profesionalisme birokrasi desa dan juga membentuk karakter kepemimpinan lokal yang baik. 


\section{Gambar 2. Model Penguatan Kelambagaan Desa Wisata Melalui Praktik Pemberdayaan}

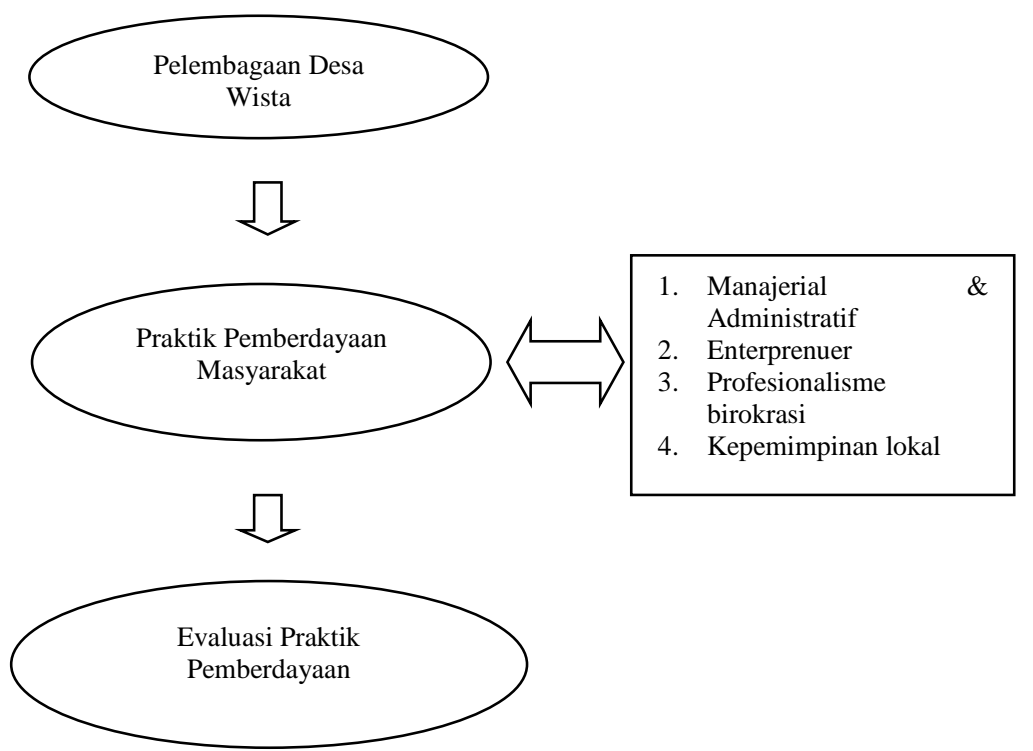

Sumber: diolah dari hasil kajian

\section{Daftar Referensi}

Ahdika, A. (2018). Model Grey (1,1) dan Grey-Markov pada Peramalan Realisasi Penerimaan Negara Atina. Fourier, 1 - 12.

Aryani, S. W., Sunarti, \& Ari, D. (2017). Analisis Dampak Pembangunan Pariwisata pada Aspek Ekonomi dan Sosial Budaya Masyarakat (Studi Kasus pada Desa Wisata Bejiharjo , Kecamatan Karangmojo , Kabupaten Gunungkidul, D.I.Yogyakarta). Jurnal Administrasi Bisnis (JAB), 142-146.

Asri, Y., \& Permana, D. (2019). Peramalan Penerimaan Pajak Negara Indonesia Tahun 2019 Menggunakan Metode Pemulusan Eksponensial Ganda Tipe Brown. Journal of Mathematic, 70-74.

Desiati, R. (2013). Pemberdayaan Masyarakat melalui Pengelolaan Program Desa Wisata. Diklus, 253-262.

Dinarjito, A. (2017). Pengelolaan Penerimaan negara Bukan pajak: Studi kasus pada kantor pertanahan Wilayah Provinsi Daerah Istimewa Yogyakarta. Manajemen Keuangan Publik, $57-69$.

Fitriana, L. N., \& Utami, W. S. (2012). Kajian Tentang Kesiapan Desa Margomulyo, Jorojero, Margorejo,Kedungrejo, Dan Gaji Untuk Menjadi Deda Wisata (Tourism Village) Di Kecamatan Kerek Kabupaten Tuban. Swara Bhumi.

Ginting, A. M. (2015, Februari 1). Strategi perpajakan 2015. VII, pp. 13 - 16.

Haris, A. (2014). Memahami Pendekatan Pemberdayaan Masyarakat melalui Pemanfaatan Media. Jupiter, 50 - 62.

Hermiyanty, W. A. (2017). Dampak Keberadaan Obyek WIsata Waduk Sermo terhadap Perubahan Sosial EKonomi Maysrakat di Sremo, Kulon Progro Daerah Istimewa Yogyakarta.Journal of Chemical Information and Modeling, 1-15.

Hermiyanty, W. A. (2017). Dampak Keberadaan Obyek WIsata Waduk Sermo terhadap Perubahan Sosial EKonomi Maysrakat di Sremo, Kulon Progro Daerah Istimewa Yogyakarta. Journal of Chemical Information and Modeling, 1 - 15.

Hermiyanty, W. A. (2017). Konsep Desa Wisata Hutan Mangrove di Desa Bedono Kecamatan Sayung Kabupaten Demak. Journal of Chemical Information and Modeling, 1-58. 
Hery, H. (2016). Dampak pengembangan desa wisata nglanggeran terhadap ekonomi masyarakat lokal. Jurnal Pariwisata, 105-117.

I G. A. O. Mahagangga, I. B. (2016). Pemetaan Jalur " Paket Wisata Pedesaan" di Desa Wisata Panglipuran, Kecamatan Bagli, Kabupaten Bangli. Udayana Mengabdi, 1 - 6.

Indrawati, D. R. (2016). Pemberdayaan Masyarakat Dalam Pengelolaan Das Mikro: Konsep Dan Implementasi. Jurnal Kawistara, 175 - 187.

Kiswantoro, A. (2014). Pengaruh even Budaya rasulan terhadap peningkatan kunjungan wisatawan di Goa Pindul Gunung Kidul. Kepariwisataan, 23 - 24.

Maryam, D. (2015). Perencanaan Partisipatif dalam Pemberdayaan Masyarakat (Studi Kasus Pelaksanaan Musyawarah Perencanaan Pembangunan (Musrenbang) di Desa Kebumen Kecamatan Sumberjo Kabupaten Tanggamus). Ilmu Dakwah dan Pengembangan Komunitas, 1-21.

Matdoan, U. (2015). Peranan Program PNPM - Mandiri Pedesaan dalam mendorong Partisipasi dan Pemberdayaan Masyarakat Lokal. Biology Science \& Education, 83-93.

Muchammad Sugianto, A. D. (2016). Pengembangan Desa Wisata Berbasis Kemitraan di Desa Koloray Kabupaten Pulau Morotai. Sosiologi USK, 155 - 174.

Mustangin, D. K. (2017). Pemberdayaan Masyarakat Berbasis Potensi Lokal Melalui Program Desa Wisata di Desa Bumiaji. SOSIOGLOBAL Jurnal Pemikiran dan Penelitian Sosiologi, 59-72.

Permadi, L. A., \& Asmony, T. (2018). Identifikasi Potensi Desa Wisata di Kecamatan Jerowaru, Lombok Timur. Jurnal Pariwisata Terapan, 33 - 45.

Prasiasa, D. P. (2017). Strategi Pengembangan dan Pemberdayaan Masyarakat Desa Wisata Timbrah Kecamatan Karang Asem, Kabupaten Karang Asem. STIM I Handayani (pp. 103 126). Denpasar: STIM I Handayani.

Pravasanti, Y. A. (2018). Dampak Kebijakan dan Keberhasilan Tax Amnesty Bagi Perekonomian Indonesia. Ilmiah Akuntansi, 84-94.

Putra, A. S. (2015). Pola kemitraan pariwisata dalam manajemen atraksi desa wisata pampang kota Samarinda. Pariwisata, 189 - 200\.

Putra, T. R. (2013). Peran Pokdarwis dalam Pengembangan Atraksi Wisata di Desa Wisata Tembi, Kecamatan Sewon-Kabupaten Bantu. Pembangunan wilayah dan kota, 225 - 235.

Revida, E. (2019). Kontribusi Keterampilan Manajemen terhadap Efektivitas Desa Wisata di Desa Wisata Meat Toba Samosir Sumatera Utara. JUPIIS (Jurnal Pendidikan Ilmu - Ilmu Sosial), 365-373.

Santoso, U., \& Setiawan, J. M. (2009). Tax Amnesty dan Pelaksanaannya di Beberapa Negara: Perspektif Bagi Pebisnis Indonesia. Sosiohumaniora, 111 - 125.

Sihombing, B., \& Smanjuntak, K. G. (2019). Peran Kompetensi Sumber Daya Manusia Pengelola Homestay Berbasis Entrepreneurship di Desa Silimalombu Samosir Dalam Meningkatkan Minat Wisatawan Mancanegara Berkunjung ke Kabupaten Samosir. Akomodasi Agung.

Srirejeki, K. (2015). Tata Kelola Keuangan Desa. Jurnal AKuntansi dan Bisnis, 33 - 37.

Syamsi, S. S. (2015). Nawa - Cita Jokowi - JK dalam Paradigma Pembangunan Ekonomi. Surya Octagon Interdisciplinary Journal of Science \& Technology, 72 - 100.

Wahidah, A. N. (2017). Pengaruh Tax Amnesty, Pertumbuhan Ekonomi Kepatuhan Wajib Pajak Terhadap Penerimaan Pajak di KPP Pratama Pekanbaru Tampan. El - Riyasah, 20 - 29.

Wahyuni, M. A. (2017). Studi Kemitraan Desa adat dengan pelaku usaha wisata untuk pengembangan Ekowisata lovina di Kabupaten Buleleng. Media Komunikasi Geografi, 14 23.

Waluyo, H. (2017). Peran musium Tani Jawa Indonesia dalam peningkatan kinerja desa wisata Candran Bantul. Journal of Chemical Information and Modeling, 1-58.

Wiwin, I. W. (2019). Faktor sukses dalam pengembangan wisata pedesaan. Pariwisata Budaya, 2529. 